\title{
Screening for antioxidant activity of vegetable and fruit by-products and evaluating the ability of coffee sediment to preserve fish meal
}

\author{
Ha Thi Hue ${ }^{1} \cdot$ Ho Trung Tinh ${ }^{2} \cdot$ Nguyen Van Bao ${ }^{1} \cdot$ Phan Thi Anh Dao ${ }^{1}$
}

Received: 24 March 2020 / Accepted: 9 June 2020 / Published online: 25 June 2020

(c) Springer Nature Switzerland AG 2020

\begin{abstract}
In this study, we collected and prepared ethanol extracts from 30 vegetable and fruit by-products and screened for antioxidant activities using three methods, including determination of total phenolic content (TPC), 2,2-diphenyl-1-picrylhydrazyl free radical scavenging assay (DPPH assay), and ferric reducing/antioxidant power assay (FRAP assay). The coffee sediment (TN-16) and ginger peel extract (TN-17) showed vigorous activities and higher than those of other samples $(p<0.05)$. The TPC in TN-16 and TN-17 were $66.14 \mathrm{mgGAE} / \mathrm{g}$ and $146.52 \mathrm{mgGAE} / \mathrm{g}$, respectively. For the DPPH assay, the $\mathrm{IC}_{50}$ inhibited the values of $16.73 \mu \mathrm{g} / \mathrm{mL}$ with $\mathrm{TN}-17$ and $33.57 \mu \mathrm{g} / \mathrm{mL}$ with TN-16. For the FRAP, a significant difference in absorbance was observed between all samples $(p<0.05)$, and $\mathbf{T N}-\mathbf{1 6}$ and $\mathbf{T N}-\mathbf{1 7}$ have strong activities with higher absorbances. Besides, fifteen compounds may present in TN-16 namely, metiamide, manitol, 3-amino phenol, malicyamide, phenyl ethanolamine, 3-methoxyamphetamine, caffeine, nisoldipine, doxenitoin, dicyclohexyl phthalate, febuprol, 2.4 xylidine, glycerol 2-palmitate, 4-(benzylamino) phenol, o-toluidine were identified by HPLC-EIS-MS. In addition, the coffee sediment extract was investigated the ability to preserve fish meal in 30 days at the room temperature. The result showed that the coffee sediment was the potent extract for the protection of fish meal against lipid peroxidation as compared to synthetic antioxidants.
\end{abstract}

Keywords Natural antioxidant · DPPH ·TPC · FRAP · By-product · Coffee sediment

\section{Introduction}

Fish meal is a valuable aqua-feed and pet-food ingredient due to the high content of protein and the nutritive value of lipids, essential amino acids and other constituents [1]. The quality of fish meal can deteriorate due to the activities of insects, microorganisms, animals, processing methods as well as high temperatures and excess moisture [2]. These factors may stimulate fish meal spoilage during storage because of the high content of unsaturated fats [3]. Antioxidants are the best choice to delay the onset of oxidation by preventing the formation of free radicals. Thus, the overall purpose of using antioxidants is to enhance oxidative stability for a reasonable length of time.
Several synthetic antioxidants are authorized for use as feed additives such as ethoxyquin (EQ) and butylated hydroxytoluene (BHT). They are generally added to fish meal and fish oil, respectively, to limit lipid oxidation [4]. However, the direct application of synthetic inhibitors to fish meal is currently restricted due to considerations related to their safety. While the use of synthetic antioxidants and antibacterials to maintain the quality of seafood products has become a common method, consumer concern about their risks has heightened scientific interest in the reduction of synthetic additives or their replacement by natural alternatives [1].

The food processing industries have generated a large amount of phenolic-rich by-products, which could be

Phan Thi Anh Dao, daopta@hcmute.edu.vn | ${ }^{1}$ Faculty of Chemical and Food Technology, Ho Chi Minh City University of Technology and Education, Ho Chi Minh City, Vietnam. ${ }^{2}$ Faculty of Natural Sciences, Thu Dau Mot University, Thủ Dầu Một, Vietnam. 
valuable natural sources of antioxidants and antibacterials. Some of these by-products have been the subject of investigations and have been demonstrated to be effective sources of phenolic antioxidants and antibacterials. Several antioxidants have been extracted from plant sources such as tea, sesame, wild rice, rice hulls, and crude plant drugs, citrus peels and seeds, grape seeds, mango seed kernels, canola, sunflower seeds, and sesame [5-11].

Most of the waste in the processing of fruits and vegetables are: nuts, leaves, stems, bark, and roots that contain high-value natural compounds, useful for human health [12]. The fruit and vegetable by-products should be used as a potential source of natural antioxidant compounds. Besides, the utilization of these by-products contributes significantly to reducing the amount of waste, and to prevent environmental pollution and achieve the sustainable development goals. The by-products can be processed into functional foods rather than being discarded [12].

In this study, we selected 30 by-products to investigate their antioxidant activity by using different tests, including DPPH free radical scavenging assay, ferric reducing/ antioxidant power (FRAP) assay and determination of total phenolic contents (TPC). We hope that the selected byproducts could be a potential source of natural antioxidants that could be used as therapeutic agents in preventing or slowing the oxidation in fish meal.

\section{Materials}

\subsection{Samples}

By-products were obtained from the shops at Long Phuoc Market, District 9, HCM, in August 2017. The by-products were collected, thoroughly washed under tap water to remove impurities such as dirt, dust, microflora on the surface. Then they were dried in a hot air-blowing oven at $60{ }^{\circ} \mathrm{C}$ for $5 \mathrm{~h}$ to a moisture content of about $10 \%$ and ground into a fine powder using a blender. The voucher samples (number sample on Table 1) were preserved at the department of food technology of the Ho Chi Minh City University of technology and education.

\subsection{Chemicals}

Gallic acid and Folin-Ciocalteu reagent were purchased from Sigma Chem. Co. DPPH, acid trichloroacetic (TCA) were obtained from Merck (Darmstadt, Germany). Ethanol solvent $(\mathrm{EtOH})$, potassium iodide $(\mathrm{KI})$, potassium hexacyanoferrate $\left(\mathrm{K}_{3}\left[\mathrm{Fe}(\mathrm{CN})_{6}\right]\right)$, ferric chloride $\left(\mathrm{FeCl}_{3}\right), \mathrm{Na}_{2} \mathrm{CO}_{3}$ were purchased from China with the highest grade impurities.

SN Applied Sciences

a SPRINGER NATURE journal

\subsection{Preparation of samples}

$100 \mathrm{~g}$ of dried, powdered sample from each of the vegetable and fruit by-products was extracted with $300 \mathrm{~mL}$ of $96 \%(\mathrm{v} / \mathrm{v})$ ethanol at $65^{\circ} \mathrm{C}$ in a Soxhlet apparatus (reflux, $3 \mathrm{~h}, \times 3$ ). Then, the extracts were filtered using Whatman $\mathrm{N}^{0} 4$ filter paper, and the solvents were concentrated by a rotary evaporator under reduced pressure conditions (20 $\mathrm{hPa}, 50^{\circ} \mathrm{C}$ ) to recover the ethanol extracts and stored at $4^{\circ} \mathrm{C}$. Ethanol was used in this study as it is a green solvent with low risk for acute or chronic toxicity as compared to some other solvents. The percentage yield of extracts ranged from $0.35-24.08 \% \mathrm{w} / \mathrm{w}$.

\subsection{DPPH free radical scavenging assay}

The DPPH radical scavenging activity of the extracts was determined according to the methodology described by $P$. Molyneux [13]. First, $1.5 \mathrm{~mL}$ of a $0.1 \mathrm{mM}$ solution of DPPH in $90 \%$ ethanol was added to $1.5 \mathrm{~mL}$ of each extract (at 50 $\mu \mathrm{g} / \mathrm{mL}$ ) in $90 \%$ ethanol. After 30 min incubation at room temperature in the dark, the absorbance was measured at $517 \mathrm{~nm}$ by Hitachi UH-530 spectrophotometer. The percent inhibition (I\%) was calculated as $(A-B / A) \times 100$, where $A$ is the absorbance of the test sample, and $B$ is the absorbance of the blank sample. The half maximal inhibitory concentration $\left(\mathrm{IC}_{50}\right)$ was determined using the mean values of data from three determinations at concentrations of 100 , $50,25,10 \mu \mathrm{g} / \mathrm{mL}$ in $90 \%$ ethanol. Trolox used as a positive control was used at various concentrations $(1.0,2.5,5.0$, $10.0 \mu \mathrm{M})$.

\subsection{Ferric reducing/antioxidant power assay}

The experimental procedure was based on the method of Benzie [14]. Extracts $(0.1,0.5$ and $1 \mathrm{mg})$ were mixed with $1.0 \mathrm{~mL}$ of $2.0 \mathrm{M}$ phosphate $(\mathrm{pH} 6.6)$ and $1.0 \mathrm{~mL}$ potassium ferricyanide $1 \%$. The mixture was incubated at $50{ }^{\circ} \mathrm{C}$ for $20 \mathrm{~min}$. Then $1.0 \mathrm{~mL}$ of $10 \%$ TCA was added and centrifuged at $2000 \times \mathrm{g}$ for $10 \mathrm{~min}$. The supernatants $(1.0 \mathrm{~mL})$ were mixed with distilled water $(1.0 \mathrm{~mL})$ and ferric chloride $0.1 \%(0.2 \mathrm{~mL})$ and measured at $700 \mathrm{~nm}$ wavelength.

\subsection{Determination of the total phenolic content}

The TPC was determined using the Folin-Ciocalteu reagent [15]. Firstly, $1300 \mu \mathrm{L}$ of sample solutions mixed with 1000 $\mu \mathrm{L}$ of Folin-Ciocaltue reagent (1:5) and incubated for $5 \mathrm{~min}$. Then, $700 \mu \mathrm{L}$ of $\mathrm{Na}_{2} \mathrm{CO}_{3} 1 \mathrm{M}$ solution was added and mixed thoroughly. After 30 minutes of incubation in the dark, the absorbance of samples was measured at $730 \mathrm{~nm}$. Results 


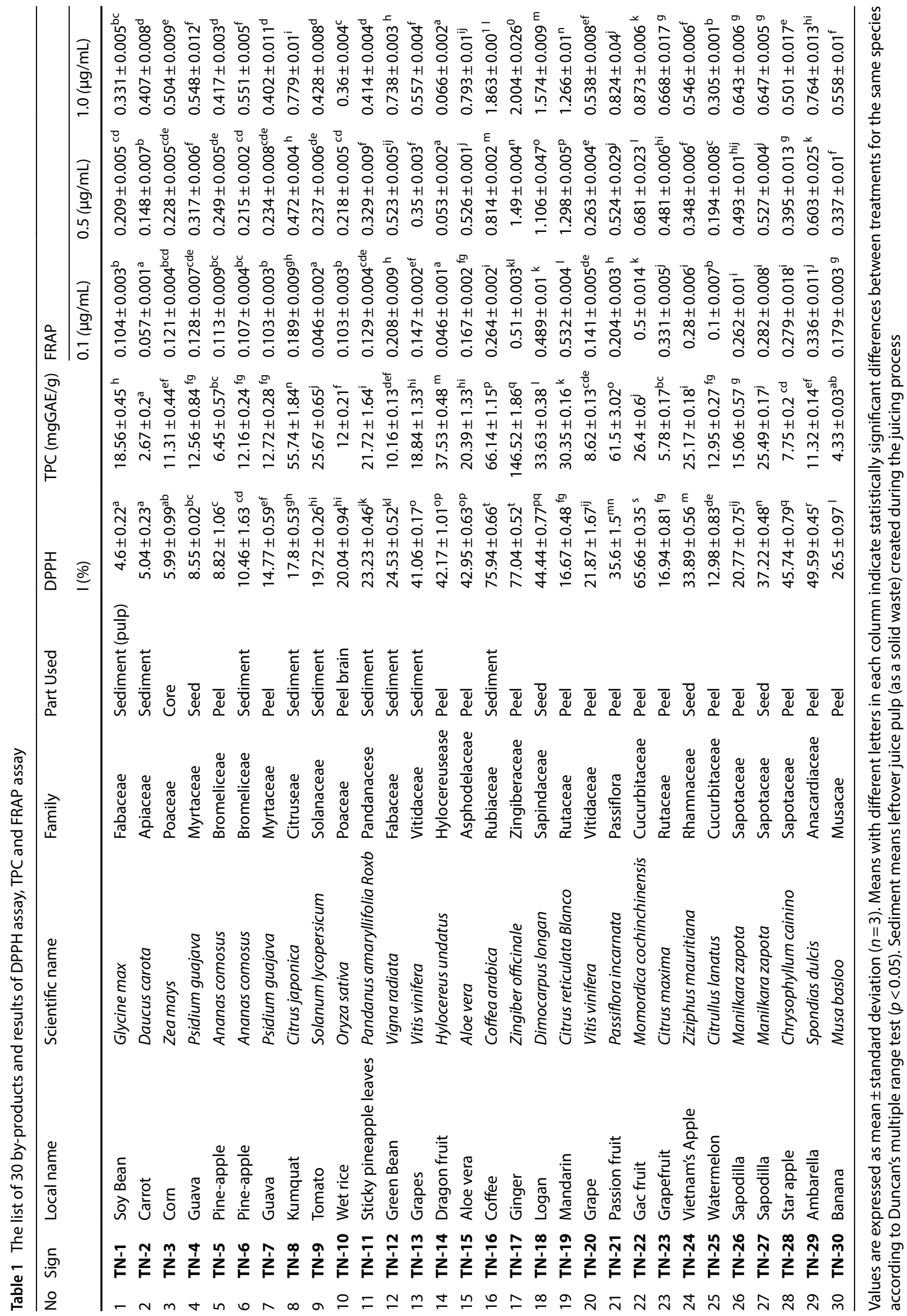


were expressed as mg gallic acid equivalents in $1 \mathrm{~g}$ of the dried sample (mgGAE/g), which is based on the standard curves at concentrations of $1,5,10,15$ and $20 \mu \mathrm{g} \cdot \mathrm{mL}^{-1}$ $\left(R^{2}=0.9976\right)$.

\subsection{HPLC-EIS-MS analysis of coffee sediment extract}

The compositions of the ethanolic extract of coffee sediment (TN-16) were analyzed by HPLC-EIS-MS technique using an Agilent 1200 series (USA) equipped with ESI-MS system (micrOTOF-QII Bruker Daltonic, Germany). A ACE3- $C_{18}$ (4.6 $\times 150 \mathrm{~mm}, 3.5 \mu \mathrm{m}$, Merck, Germany) column was used. The mobile phase consisted of $0.1 \%$ formic acid in water $(\mathrm{v} / \mathrm{v}$, solvent $\mathrm{A}$ ) and $0.1 \%$ formic acid in methanol $(\mathrm{v} / \mathrm{v}$, solvent $B$ ). The gradient program was as follows: 0 min 95:5 (A:B\% ratio), 2 min 5\% B, 25 min 100\% B, 30 min 100\% B. The flow rate was $0.5 \mathrm{~mL} / \mathrm{min}$, the column temperature was $40^{\circ} \mathrm{C}$, and the sample injection volume was $20 \mu \mathrm{L}$. The optimized ESI-MS operating conditions were as follows: nebulizer gas at $1.2 \mathrm{bar}$, dry gas heater temperature of $200^{\circ} \mathrm{C}$, and at a flow rate of $0.8 \mathrm{~mL} / \mathrm{min}$. The mass scan range was set at $\mathrm{m} / \mathrm{z}$ 150-2000.

\subsection{The production process and preservation of fish meal}

Fish meal was produced according to a method by Dambergs with some modifications [16]. Raw materials were small fish, fish fillet by-products which were washed, and then heated in $10 \mathrm{~min}$ to precipitate proteins, destroy microorganisms, separate lipids, and water. The materials were finely ground, mixed with ethanol $80 \%$ in the ratio of $1: 2$ $(\mathrm{w} / \mathrm{v})$, and then heated at $80^{\circ} \mathrm{C}$ in $15 \mathrm{~min}$. The mixture was filtered to remove the solvents. Ethanol was added to the mixture, and the procedure was repeated for one more time. After that, the mixture was dried at $80^{\circ} \mathrm{C}$ in $3 \mathrm{~h}$ to approximately $20 \%$ moisture content, ground into a fine fish meal.

The fish meal was divided into four parts. Each of these three parts was mixed with BHT (150 ppm), coffee sediment extract ( $300 \mathrm{ppm}$ ), and a blank sample. The four pieces were dried by a air-blowing oven at $80^{\circ} \mathrm{C}$ in $1 \mathrm{~h}$ to decrease the moisture content to below $10 \%$ before being graded by a $1 \mathrm{~mm}$ sieve. The obtained product was stored in polyethylene (PE) bags at room temperature $\left(32 \pm 2{ }^{\circ} \mathrm{C}\right)$ and used for determining nutrient compositions and peroxide values during 1 month of storage at room temperature.

\subsection{Determination of peroxide value of the fish meal}

The oxidation of fat in the fish meal was evaluated by peroxide value (PV), which was determined by the method described by Cox [17]. To start, moved 0.5 gram of sample into a $250 \mathrm{~mL}$ erlenmeyer flask and added 0.5 $\mathrm{mL}$ of a saturated solution of $\mathrm{Kl}$ and $20 \mathrm{~mL}$ of a $3: 2(\mathrm{v} / \mathrm{v})$ acetic acid-chloroform mixture. The flask was kept in the dark space for $5 \mathrm{~min}$ before the addition of $30 \mathrm{~mL}$ of distilled water and $1 \mathrm{~mL}$ of a $1 \%$ starch solution. The solution turned into a deep purple color and titrated until turning to colorless. It has carried out a blank titration under the same conditions.

\subsection{Statistical analysis}

All results were expressed as mean $\pm \mathrm{SD}$ (standard deviation). The significant differences between means were determined by analysis of variance (ANOVA) using the Duncan's multiple range tests was applied at a level of $p<0.05$. Statistical calculations were carried out by SPSS 15.0 for Window Evaluation Version (IBM Corporation, USA).

\section{Result and discussion}

\subsection{DPPH free radical scavenging assay}

30 EtOH extracts prepared from 30 selected by-products were screened for their antioxidant activities by DPPH and FRAP assay (Table 1). For DPPH assay, all samples were carried out at a concentration of $50 \mu \mathrm{g} / \mathrm{ml}$. Of the extracts assayed, 30 extracts $(100 \%)$ demonstrated DPPH inhibitory activity at $50 \mu \mathrm{g} / \mathrm{ml}$, among which 27 (90.0\%) showed weak activities with I \% under $50 \%$. It is showed that most samples have weak antioxidant activity. Besides, the strong active extracts for antioxidant activity were ginger (TN-17) and coffee sediment (TN-16), followed by gac fruit (TN-22) with the percent inhibition values of $77.04 \%, 75.94 \% 65.66 \%$, respectively. Three extracts were tested further for determining $I C_{50}$ values of $16.73 \mu \mathrm{g} / \mathrm{mL}, 33.57 \mu \mathrm{g} / \mathrm{mL}$, and $42.85 \mu \mathrm{g} / \mathrm{mL}$, respectively. $\mathrm{IC}_{50}$ of trolox was $8.7 \mu \mathrm{M}(2.2 \mu \mathrm{g} / \mathrm{ml})$.

The DPPH analysis is a quick and simple assay that guarantees reliable results and needs only a UV-Vis spectrophotometer to carry out, which probably explains its widespread use in antioxidant screening [18]. The effect of antioxidants on DPPH radical scavenging is due to their hydrogen donating ability. Base on analyzing the results obtained in DPPH assay, it was noticed that extracts act as good hydrogen donating agents, thereby bleaches the DPPH absorbance at $517 \mathrm{~nm}$. 


\subsection{Ferric reducing/antioxidant power (FRAP) assay}

In general, the reduction capacity of the samples with increasing sample concentration levels were shown in Table 1. It is observed that the higher the concentration, the greater the reduction capacity, and the stronger the antioxidant activity. At the highest concentration (1.0 $\mathrm{mg}$ ), there was a significant difference in absorbance values between the three most active samples, ginger peel $(\mathbf{T N}-17,2.004)$ and coffee sediment $(\mathrm{TN}-16,1.863)$, logan seed $(\mathbf{T N}-\mathbf{1 8}, \mathbf{1 . 5 7 4})(p<0.05)$. This is suggested that these samples inhibited the ability to reduce $\mathrm{Fe}^{3+}$ to $\mathrm{Fe}^{2+}$ was higher than that of the other samples.

Reducing properties is related to the presence of potent reducing agents and the antioxidant activity of the potent reducing agents is attributed to the breakdown of free radicals by the release of a hydrogen atom [19-20]. It was suggested that antioxidant properties coincide with an increase in reducing capacity. Therefore, the intense antioxidant activity of the extract from the ginger shell and coffee grounds may correlate with the reducing ability of the extracts.

\subsection{Determination of the total phenolic content}

The total phenolic contents in the extract samples were shown in Table 1. The values of total phenolic content of the samples were from 2.67 to $146.52 \mathrm{mgGAE} / \mathrm{g}$. The extract from ginger peel (TN-17) showed the highest value of total phenolic content (146.52 mgGAE/g), following by the extract from coffee sediment (TN-16) and kumquat peel (TN-8) with $66.14 \mathrm{mgGAE} / \mathrm{g}$ and $55.74 \mathrm{mgGAE} / \mathrm{g}$, respectively. The lowest value of total phenolic content belonged to the extract from carrot sediment (TN-2) with $2.67 \mathrm{mgGAE} / \mathrm{g}$. In general, the values of the total phenolic content in the extract samples showed a significant difference $(p<0.05)$.

The correlation between antioxidant capacity and total phenolic content in food has been extensively studied $[15,21]$. According to a study by Panusa et al. [22], the values of antioxidant activity in the DPPH test correlate with the total phenolic content in coffee grounds under different extraction conditions [22]. Two sample extracts ginger peel (TN-17), and coffee sediment (TN16) had not only high DPPH inhibitory activity but also potent phenolic content.

In fact, coffee sediment extract is more suitable to preserve fish meal because of its high availability and affordability. That is the reason coffee sediment extract was chosen to investigate its chemical compositions and the ability to preserve fish meal.

\subsection{Chemical composition of coffee sediment}

Fifteen compounds have been identified in TN-16 by high performance liquid chromatography with MS probes (Table 2).

Among them, 3-amino phenol, salicyamide, phenyl ethanolamine, caffeine, and 4-(benzylamino) phenol belong to the phenolic group. In particular, caffeine is a potent antioxidant compound. The high levels of chlorogenic acid and caffeine in coffee grounds suggest the potential for using them as a natural source of antioxidants [22].

\subsection{The evaluation of fish meal quality}

The yield of producing fish meal was $20 \%$ by weight of the raw material, the yield of filtered fish meal ( $1 \mathrm{~mm}$ sieves) was $94.74 \%$ by weight of the dry fish meal. The fish meal showed nutrient compositions as follows: moisture of $10.25 \%$; total protein of $44.69 \%$; total fat of $16.81 \%$; and ash of $15.34 \%$. In commerce, fish meal has protein content of $12-66 \%$; moisture of $0-9 \%$; fat of $6 \%$ and ash of $13-21 \%$ [23]. There is variation in the protein content of the fish meal, depending on the ingredients used. Besides, the fish meal has a low ash value and the high-fat content as compared to commercial fish meal. This leads fish meal to deteriorating faster than commercial fish meal due to lipid oxidation [24].

\subsection{Determination of peroxide values of the fish meal during storage}

The ability of TN-16 for preserving fish meal was evaluated by the formation of primary oxidation products

Table 2 Identification of 15 compounds in TN-16 by HPLC-ESI-MS

\begin{tabular}{llll}
\hline No. & Compounds & {$[\mathrm{M}-\mathrm{H}]^{-}(\mathrm{m} / \mathrm{z})$} & Predicted formula \\
\hline 1 & Metiamide & 245,0871 & $\mathrm{C}_{9} \mathrm{H}_{16} \mathrm{~N}_{4} \mathrm{~S}_{2}$ \\
2 & Manitol & 205,0683 & $\mathrm{C}_{6} \mathrm{H}_{14} \mathrm{O}_{6}$ \\
3 & 3-amino phenol & 110,0601 & $\mathrm{C}_{6} \mathrm{H}_{7} \mathrm{NO}$ \\
4 & Salicyamide & 138,0551 & $\mathrm{C}_{7} \mathrm{H}_{7} \mathrm{NO}_{2}$ \\
5 & Phenyl ethanolamine & 138,0919 & $\mathrm{C}_{8} \mathrm{H}_{11} \mathrm{NO}$ \\
6 & 3-Methoxyamphetamine & 166,1225 & $\mathrm{C}_{10} \mathrm{H}_{5} \mathrm{NO}$ \\
7 & Caffeine & 217,0696 & $\mathrm{C}_{8} \mathrm{H}_{10} \mathrm{~N}_{4} \mathrm{O}_{2}$ \\
8 & Nisoldipine & 411,1502 & $\mathrm{C}_{20} \mathrm{H}_{24} \mathrm{~N}_{2} \mathrm{O}_{6}$ \\
9 & Doxenitoin & 239,1179 & $\mathrm{C}_{15} \mathrm{H}_{14} \mathrm{~N}_{2} \mathrm{O}$ \\
10 & Dicyclohexyl phthalate & 331,1908 & $\mathrm{C}_{20} \mathrm{H}_{26} \mathrm{O}_{4}$ \\
11 & Febuprol & 225,1485 & $\mathrm{C}_{13} \mathrm{H}_{20} \mathrm{O}_{3}$ \\
12 & 2,4 Xylidine & 122,0965 & $\mathrm{C}_{8} \mathrm{H}_{11} \mathrm{~N}$ \\
13 & Glycerol 2-palmitate & 330,2773 & $\mathrm{C}_{19} \mathrm{H}_{38} \mathrm{O}_{4}$ \\
14 & 4-(Benzylamino) phenol & 200,1069 & $\mathrm{C}_{13} \mathrm{H}_{13} \mathrm{NO}$ \\
15 & o-Toluidine & 108,0808 & $\mathrm{C}_{7} \mathrm{H}_{9} \mathrm{~N}$
\end{tabular}


Fig. 1 Changes in peroxide values of fish meal with different treatments during storage at room temperature. Bars represent standard deviation $(n=3)$. Different capital letters on the bars within the same treatment indicate significant differences $(p<0.05)$. The different letters on the bars within the same storage time indicate significant differences $(p<0.05)$

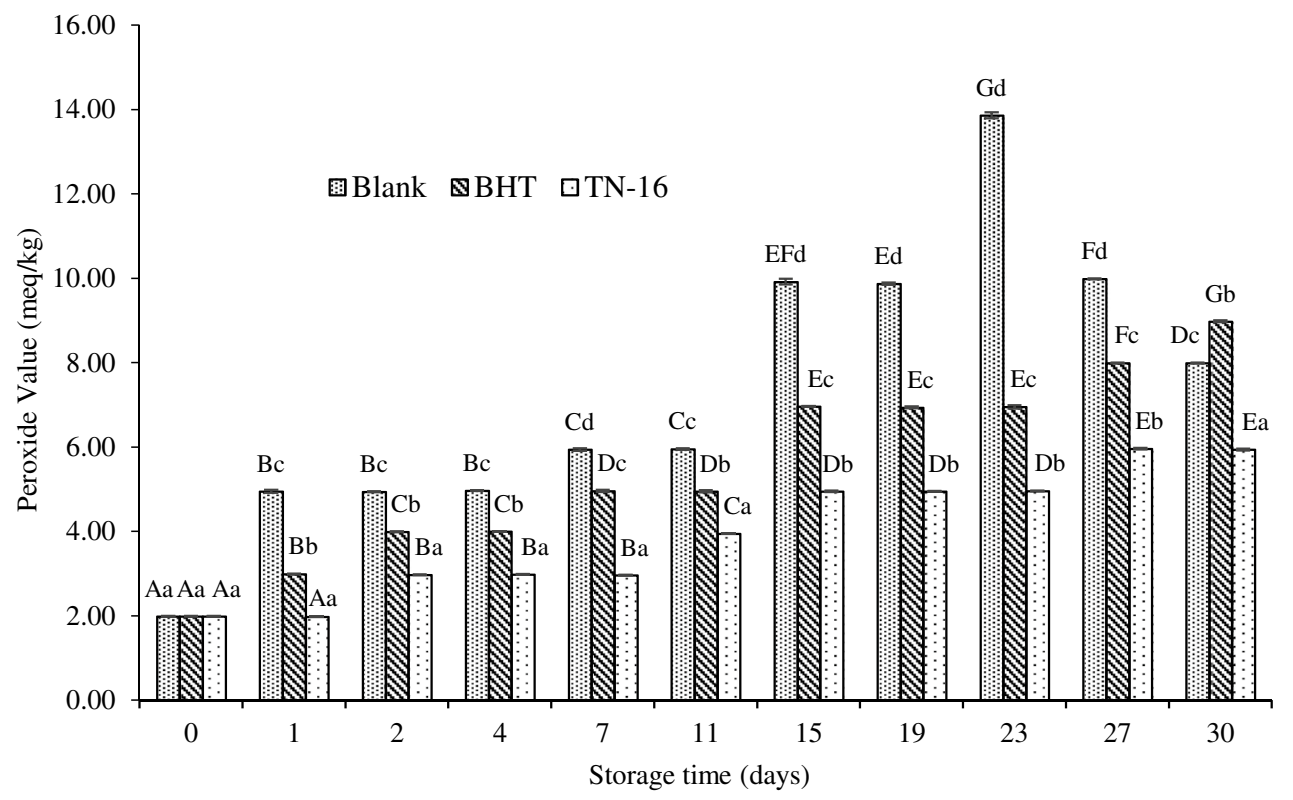

(peroxides). Figure 1 indicates the peroxide values of coffee sediment, BHT, and blank samples from homogenous fish meal samples.

Overall, peroxide values of fish meal with preservatives were lower and remained more stable than the blanks over the period shown. It was found that the peroxide values of blanks increased considerably from an initial value of $1.99 \mathrm{meq} / \mathrm{kg}$ to reach the peak at $13.86 \mathrm{meq} / \mathrm{kg}$ for the first 24 days, and decreased afterward. The values for samples with BHT were lower, rising significantly for the first 15 days (from 1.99 to $6.96 \mathrm{meq} / \mathrm{kg}$ ) and slightly for the rest $(6.94 \mathrm{meq} / \mathrm{kg}$ to $8.98 \mathrm{meq} / \mathrm{kg})$. The smallest peroxide values were found in the fish meal with extracts of coffee sediment (TN -16) with the number growing marginally from 1.99 to $5.94 \mathrm{meq} / \mathrm{kg}$ at the end of the period. The quality of fish meat products is decreased by the lipid peroxidation, which results in a reduction in nutritional quality. Coffee sediment act as antioxidant reagents that delay or prevent the formation of free radicals through different mechanisms: hydrogen atom transfer, single-electron transfer mechanism (SET), or the combination of both HAT and SET mechanisms [25].

\section{Conclusions}

In conclusion, we have carried out a systematic investigation of vegetable and fruit by-products for DPPH assay, determination of phenolic content, and ferric reducing/ antioxidant power (FRAP) assay. The results indicate a limited number of by-products that may be useful for the treatment of diseases relating to free radical damages such as coffee sediment (TN-16), ginger peel (TN-17), and gac peel (TN-22). Among them, the coffee sediment extract exhibits potent abilities to inhibit the oxidation of fish meal during storage. In Viet Nam, a large amount of fish meal is produced to meet the increasing need for domestic and foreign fisheries and aquaculture industries. On the market, coffee sediment is a highly abundant and low-cost raw material; thus, the potential for using the byproduct as a natural source of antioxidants is going to be promising.

Acknowledgements This work belongs to the project grant No: T2019-10GVT funded by Ho Chi Minh City University of Technology and Education, Vietnam.

\section{Compliance with ethical standards}

Conflict of interest All authors declare that there is no conflict of interest.

\section{References}

1. Samaneh P, Seyed MO, Alireza A (2015) Effect of plant antioxidant and antimicrobial compounds on the shelf-life of seafood-a review. Czech J Food Sci 33:195-203. https://doi. org/10.17221/593/2014-CJFS

2. Tsironi T, Houhoula D, Taoukis $P(2020)$ Hurdle technology for fish preservation. Aquac Fish 5:65-71. https://doi.org/10.1016/j. aaf.2020.02.001

3. Giulia S, Giuliana P (2016) From farm to fork: lipid oxidation in fish products. A review. Ital J Anim Sci 15:124-136. https://doi. org/10.1080/1828051X.2015.1128687

4. Lundebye AK, Hove H, Måge A, Bohne VJ, Hamre K (2010) Levels of synthetic antioxidants (ethoxyquin, butylated hydroxytoluene and butylated hydroxyanisole) in fish feed and commercially 
farmed fish. Food Addit Contamin: part A 27:1652-1657. https ://doi.org/10.1080/19440049.2010.508195

5. Ramarathnam N, Osawa T, Ochi H, Kawakishi S (1995) The contribution of plant food antioxidants to human health. Trends Food Sci Technol 6:75-82. https://doi.org/10.1016/S0924 -2244(00)88967-0

6. Alessandra B, Marie EC, Hubert R, Claudette B (1998) Antioxidant activity and phenolic composition of citrus peel and seed extracts. J Agric Food Chem 46:2123-2129. https://doi. org/10.1021/jf9709562

7. Jayaprakasha GK, Singh RP, Sakariah KK (2001) Antioxidant activity of grape seed (Vitis vinifera) extracts on peroxidation models in vitro. Food Chem 73:285-290. https://doi.org/10.1016/S0308 -8146(00)00298-3

8. Puravankara D, Boghra V, Sharma RS (2000) Effect of antioxidant principles isolated from mango (Mangifera indica L.) seed kernels on oxidative stability of buffalo ghee (butter-fat). J Sci Food Agric 80:522-526. https://doi.org/10.1002/(SICI)10970010(200003)80:4<522::AID-JSFA560>3.0.CO;2-R

9. Naczk M, Amarovicz R, Sullivan A, Shahidi F (1998) Current research developments on polyphenolics of rapeseed/canola. A review. Food Chem 62:489-502. https://doi.org/10.1016/S0308 -8146(97)00198-2

10. Kubicka E, Jedrychowski L, Amarowicz R (1999) Effect of phenolic compounds extracted from sunflower seeds on native lipoxygenase activity. Grasas Aceites 50:3206-3209. https:// doi.org/10.3989/gya.1999.v50.i2.647

11. Shahidi F, Amarovicz R, Abou-Gharbia HA, Shehata AAY (1997) Endogenous antioxidants and stability of sesame oil as affected by processing and storage. J Am Oil Chem Soc 74:143-147. https ://doi.org/10.1007/s11746-997-0159-0

12. Chala G (2015) Review on potential use of fruit and vegetables by-products as a valuable source of natural food additives. Food Sci Qual Manag 45:57-58

13. Molyneux $\mathrm{P}$ (2004) The use of stable free radical diphenylpicrylhydrazyl (DPPH) for estimating antioxidant activity. Songklanakarin J Sci Technol 26:211-219

14. Benzie IF, Strain JJ (1999) Ferric reducing/antioxidant power assay: direct measure of total antioxidant activity of biological fluids and modified version for simultaneous measurement of total antioxidant power and ascorbic acid concentration. Methods Enzymol 299:15-27. https://doi.org/10.1016/S0076 -6879(99)99005-5

15. Velioglu YS, Mazza G, Gao L, Oomah BD (1998) Antioxidant activity and total phenolics in selected fruits, vegetables, and grain products. J Agric Food Chem 46:4113-4117. https://doi. org/10.1021/jf9801973

16. Dambergs N (1959) Extractives of fish muscle. 2. Solvent-water ratio in extraction of fat and water-solubles. J Fish Board Can 16:63-71. https://doi.org/10.1139/f59-008

17. Cox HE, Pearson D (1962) The chemical analysis of foods. Chemical Publishing Company, New York

18. Ali M, Imran M, Nadeem M, Khan MK, Sohaib M, Suleria HR, Bashir R (2019) Oxidative stability and sensoric acceptability of functional fish meat product supplemented with plant-based polyphenolic optimal extracts. Lip Health Dis 18:35. https://doi. org/10.1186/s12944-019-0982-y

19. Negi PS, Chauhan AS, Sadia GA, Rohinishree YS, Ramteke RS (2005) Antioxidant and antibacterial activities of various seabuckthorn (Hippophae Rhamnoides L.) seed extracts. Food Chem 92:119-124. https://doi.org/10.1016/j.foodc hem.2004.07.009

20. Gordon MH (1990) The mechanism of antioxidant action in vitro. In: Hudson BJF (ed) Food antioxidants. Elsevier Applied Food Science Series. Springer, Dordrecht, pp 1-18

21. Shan B, Cai YZ, Sun M, Corke H (2005) Antioxidant capacity of 26 spice extracts and characterization of their phenolic constituents. J Agric Food Chem 53:7749-7759. https://doi.org/10.1021/ jf051513y

22. Panusa A, Zuorro A, Lavecchia R, Marrosu G, Petrucci R (2013) Recovery of natural antioxidants from spent coffee grounds. J Agric Food Chem 61:4162-4168. https://doi.org/10.1021/jf400 5719

23. Abowei JFN, Tawari CC (2011) Some basic principles of fish processing in Nigeria. Asian J Agric Sci 6:437-452

24. Hultin HO (1994) Oxidation of lipids in seafoods. In: Shahidi F, Botta JR (eds) Seafoods: chemistry, processing technology and quality. Springer, Boston, MA, pp 49-74. https://doi. org/10.1007/978-1-4615-2181-5_5

25. Norma FSS, Raúl SC, Claudia VC, Beatriz HC (2019) Antioxidant compounds and their antioxidant mechanism. Antioxidants. IntechOpen. https://doi.org/10.5772/intechopen.85270

Publisher's Note Springer Nature remains neutral with regard to jurisdictional claims in published maps and institutional affiliations. 